\title{
Research of Efficiency of the Horizontal Coating Depending on Intensity of Capillary Absorption
}

\author{
Nina Dmitriyeva, Oleg Popov, Olga Grin
}

\begin{abstract}
In this article, research of intensity of a capillary suction of horizontal waterproof coatings when using dry polymer plaster mixtures is described. Line charts of dependence of intensity of capillary absorption on the depth of dipping and mortars for waterproofing coatings are made based on test data. The following stage of experiment is modeling of horizontal waterproofing of shell limestone masonry in sandy and clay soils. Samples of stone were laid on waterproofing material. Material was applied according to the plan of experiment, in one, two and three layers on dry and wet surfaces of samples. Thus, during the research, it has been established that the intensity of capillary absorption is affected by porosity of shell limestone, soil conditions and types of waterproof coating.
\end{abstract}

Keywords: capillary absorption; horizontal coating; shell limestone; waterproofing

\section{INTRODUCTION}

The relevance of research is that in modern world most people prefer to live in ecological and energy efficient houses. One of such solutions is usage of natural stones in construction of buildings.

Taking into consideration the economic efficiency and resource-saving policy, such natural stone material is shell limestone in Ukraine and Moldova. Economic effect in construction of shell limestone buildings can be seen in up to $20 \%$ of reduction of financial costs when compared to using foam concrete blocks and is twice cheaper than brickworks as shell limestone is being mined in Ukraine and Moldova. This important factor contributes to the wide use of this material in building construction.

One of the factors influencing durability of a structure is moisture activity. It is of great relevance for materials with capillary - porous structure, for example, such as shell limestone.

However, the practice with such buildings has shown that the soil moisture has negative influence when it gets into a wall by capillary absorption from soil in case of damage, lack of or improper techniques of a horizontal waterproofing of a building. Violation or failure of waterproofing is one of the main causes of premature wear of structures, increasing of costs on restoring and repairing, and deteriorations of operational properties of the building in general.

Therefore, the research devoted to finding the optimal waterproof coatings for capillary suction control of shell limestone buildings is relevant.

Authors as Komyshev, Eremenok, Izmaylov, Figarov, Orudzhev, Tursunov and Shcherbina deal with issues of studying physical and mechanical properties of limestone shell [1-3].

Works of Alekseev, Afanasyev, Babushkin, Boyko, Bazhenov, Goncharenko, Shilin, Lukinsky, Homenko, Leonovich, Karapuzov, Plough, Meneylyuk and Dmitriyeva are devoted to issues of protection of below-ground parts of buildings and applying waterproofing.
Today, technologies of applying horizontal waterproofing coatings for protection of shell limestone constructions can conditionally be divided into the following groups: rigid; painting; plastering; injection; penetration waterproofing [1, 4]. Each of the listed types of waterproofing has its advantages and shortcomings.

In seismic regions, waterproofing is made of usual 1:2 cement mortar according to Construction Norms and Regulations of PMR 23-02-2009 "Construction in seismic regions" and DBN 1.1-12:2014 "Construction in seismic regions of Ukraine". Application of rolled waterproofing or membranes is not recommended.

Nevertheless, there are problems connected with destructions of integrity of waterproofing protection. These problems are caused by poor quality of waterproof materials; wrong horizontal waterproof coating; violation of temperature conditions when making coatings; emergence of cracks because of differences in temperatures amidst the lowquality waterproof coating; violation of technologies of constructing foundation structures.

In this work, the main emphasis is placed on the research of intensity of a capillary suction of horizontal waterproof coatings when using dry polymeric plaster mixtures.

Grigoriopolsky field shell limestone is stronger than the one from Odessa field and it corresponds to durability brand M35, while the one from Odessa to M15. The structure of materials is given in Fig. 1.

\section{RESULTS OF EXPERIMENTS}

In the experiment different symbols were accepted - the name of the shell limestone field: Odessa - A, and Grigoriopolsky $-\mathrm{B}$; the type of horizontal waterproof coating: X1 - a dry mixture of "Gidrozit BS" with addition of $25 \%$ of sand, and X2 - cement and sand mortar (1:2) with hydrophobic additive "Sika 1" in the amount of 5\%. The thickness rate of sand cement mortar layer varied from $5 \mathrm{~mm}$ to $7 \mathrm{~mm}$ or $9 \mathrm{~mm}$. The thickness rate of dry mixture "Gidrozit BS" varied from $2 \mathrm{~mm}$ to $3 \mathrm{~mm}$ or $4 \mathrm{~mm}$. For the comparison, 
the check samples (CS) have been made of cement and sand $\operatorname{mortar}(1: 2)$.

a)

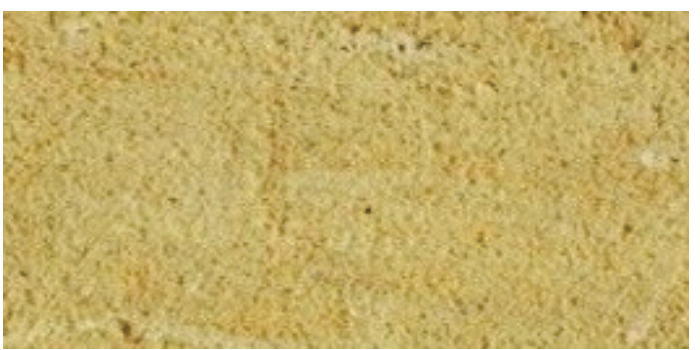

b)

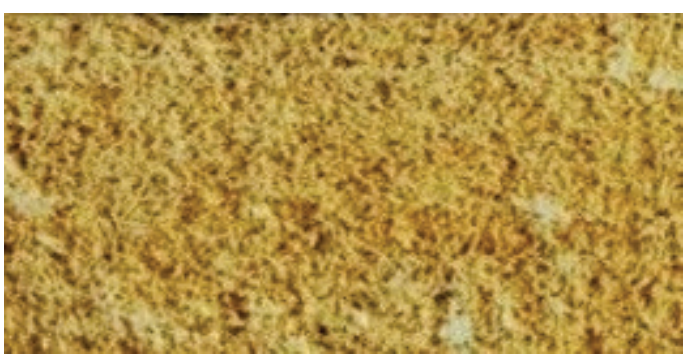

Figure 1 Samples, structure: a) Grigoriopolsky pit; b) llyinsky field

Waterproof mixture from dry powders was prepared by their gradual addition into water, mixing them constantly, until it became viscous. Then, this mixture was applied with spatula on a surface of a concrete cube. Mixing time and time of technological breaks between the subsequent coats was kept according to instructions of producers $[5,6]$.

Hydrophobized concrete cubes $100 \times 100 \times 100 \mathrm{~mm}$ in size were tested to determine the efficiency of waterproof coatings to capillary absorption. The samples sustained within 30 days after preparation were immersed into the container with water at the bottom of which the metal grid with cells $10 \times 10 \mathrm{~mm}$ in size was placed so that bottom edge of that would be in contact with water surface. Depth of dipping the samples varied between $5 \mathrm{~mm}, 10 \mathrm{~mm}$ and 15 $\mathrm{mm}$. The determination of an amount of water absorbed by a sample was fixed by weighing in various time terms ( $1 \mathrm{~min}$, $3 \mathrm{~min}, 5 \mathrm{~min}, 10 \mathrm{~min}, 15 \mathrm{~min}, 30 \mathrm{~min}, 1 \mathrm{~h}, 3 \mathrm{~h}, 6 \mathrm{~h}, 24 \mathrm{~h}$ ) as shown in Fig. 2.

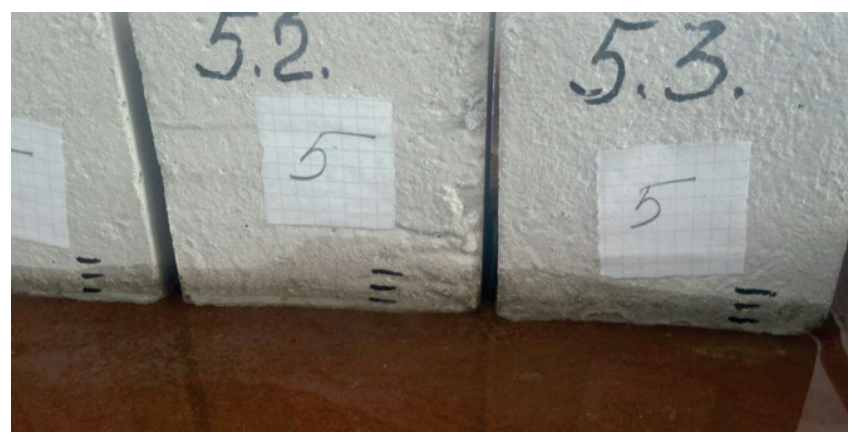

Figure 2 Capillary suction test of samples

Line charts (Fig. 3) of dependence of intensity of a capillary absorption on the depth of dipping and mortars for waterproof coatings were made based on test data.

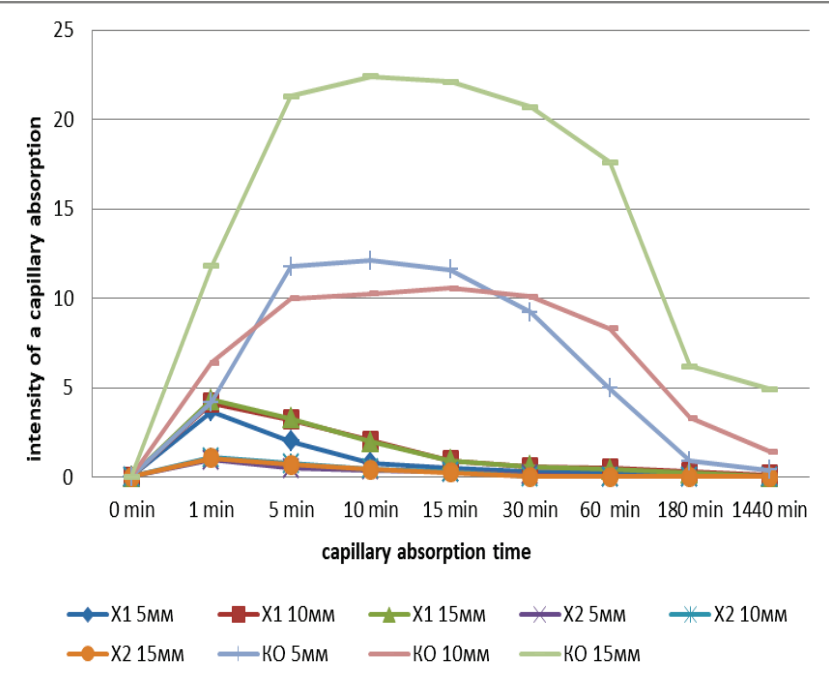

Figure 3 Line charts of intensity of a capillary absorption depending on the dipping depth and waterproof mortar

Line chart shows that when $5 \%$ of hydrophobic additive of "Sika 1" is added to sand cement mortar (X2), the capillary absorption of water is 10-17 times slower within 24 hours, and testing of mortar with Gidrozit shows decrease 3-7 times. Depth of dipping X1 and X2 samples affects the rate of intensity of a capillary absorption in no way, unlike the waterproof coating of 1:2 cement and sand mortar.

The intensity of a capillary absorption of the check samples (CS) with the depth of immersion of $15 \mathrm{~mm}$ in comparison with indexes with the depth of $5 \mathrm{~mm}$ increases approximately twice.

The following stage of experiment was the modeling of horizontal waterproofing applying at shell limestone masonry in sandy and clay soils (Fig. 4).

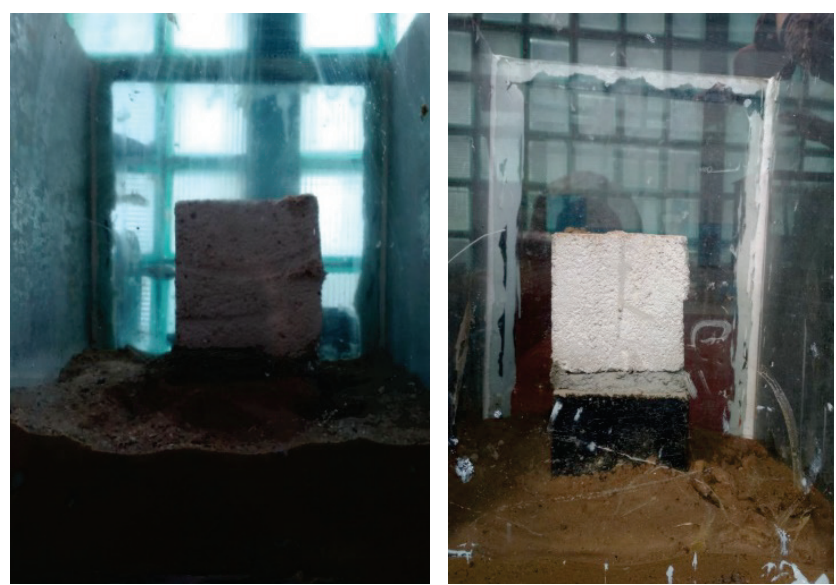

Figure 4 Model of horizontal waterproof coating: a) in sandy soil; b) in clay soil

Concrete cubes of $100 \times 100 \times 100 \mathrm{~mm}$ in size of B20 class were used as a footing model. Side faces of cubes were coated with 2 layers of BAUGUT bitumastic.

Samples of stone $50 \times 100 \times 100 \mathrm{~mm}$ in size were laid on waterproofing material. Material was applied according to the plan of experiment - in one, two and three layers on a dry and wet surfaces of the samples. To prevent gaps of coating, 
each subsequent layer was coated perpendicularly to the direction of the previous layer. Each subsequent layer was coated when previous was dry. 14 days later, the models were dipped into containers with sand and clay, thereby modeling the soil conditions.

The soil was periodically humidified, and a raising of water line was being observed during several days in a certain period of time. Results of water raising are shown in line chart (Fig. 5-8).

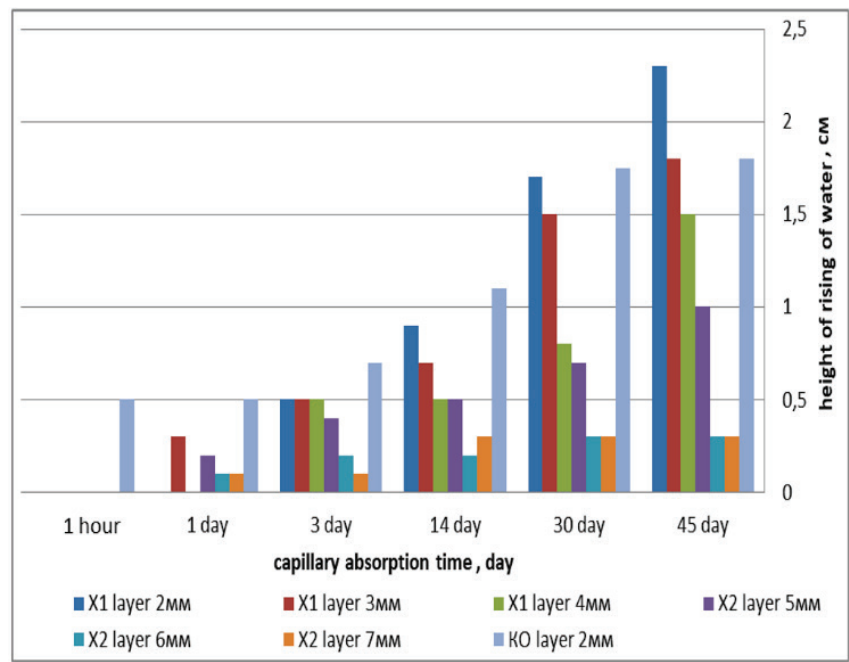

Figure 5 The line chart of dependence of height of rising of water of models $A$ in sandy conditions on the type of the waterproof coating and its thickness

As line chart shows, in an hour $0.5 \mathrm{~cm}$ rising of water was shown by samples with horizontal waterproofing coating which was made of sand cement mortar $2 \mathrm{~cm}$ thick. The same sample has maximum value of height of water rising $(1.8 \mathrm{~cm})$ after 45 days. The minimum height of rising of water $(0.3$ $\mathrm{cm}$ ) is characteristic of samples with X2 waterproof coating (sand cement mortar with 5\% hydrophobic additive "Sika 1") and with layer of $0.6 \mathrm{~cm}$ and $0.7 \mathrm{~cm}$ thick. These samples have stability of height of water rising after 14 days, that is $0.3 \mathrm{~cm}$. All other waterproof coating did not show efficient protection against capillary moisture. Height of rising of water exceeded thickness of coatings in 3 days.

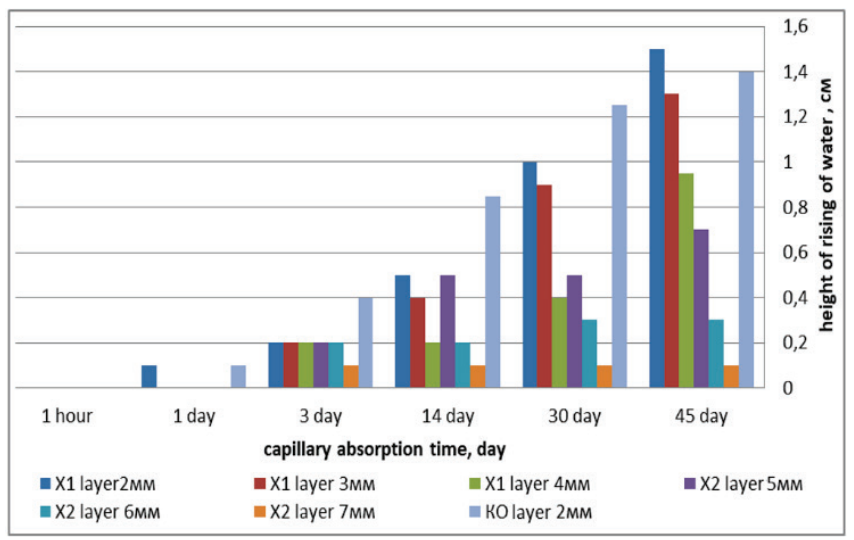

Figure 6 The line chart of dependence of height of rising of water of models B in sandy conditions on the type of the waterproof coating and its thickness
The porosity of material and orientation of stone layers concerning the surface of mixture and its mix have a significant effect on dynamics of capillary absorption.

The nature of rising of water within the first hour of $\mathrm{B}$ models is identical to A models. The difference is height of rising of water, which is 3-5 mm lower. Samples with X2 waterproof coating and with the thickness of layer of $0.7 \mathrm{~cm}$ showed height of rising of water $0.1 \mathrm{~cm}$ within a day. Height of rising of water was invariable during all research period.

It should be noted that all samples of X2 and CS showed rising of water only in the deep waterproofing coating during the research time (45 days). The waterproofing coating X1, both on models A and on models B, showed the worst results. Water passed into deep of waterproof coating: with thickness of $2 \mathrm{~mm}$ on the third day; with thickness of $3 \mathrm{~mm}$ on the $30^{\text {th }}$ day; $4 \mathrm{~mm}$ - on the $45^{\text {th }}$ day.

It can be explained that less intensive capillary absorption is characteristic for models $\mathrm{B}$ under equal conditions as the porosity of models A is $53 \%$, and models B is $29 \%$.

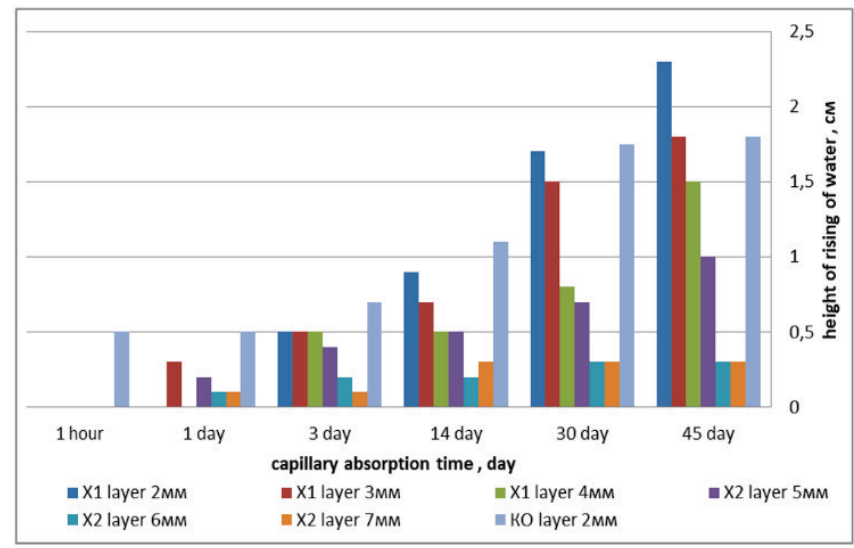

Figure 7 The line chart of dependence of height of rising of water of models $A$ in clay conditions on the type of the waterproof coating and its thickness

Decrease of intensity of rising of water on average for $40 \%$ in comparison with sandy conditions is observed.

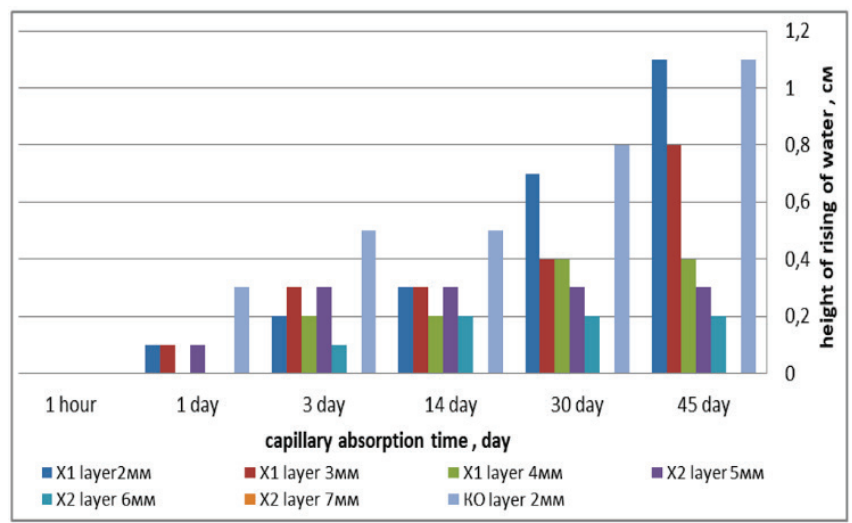

Figure 8 The line chart of dependence of height of rising of water of models B in clay conditions on the type of the waterproof coating and its thickness

Regardless of a type of model the X2 waterproofing coating $7 \mathrm{~mm}$ thick has rather high resistivity to capillary absorption, as models $\mathrm{A}$ and $\mathrm{B}$ have minimum or zero 
indexes of height of rising of water. The curve of a depression of a capillary stream from a clay soil into a body of samples (X2, CS and X1 $4 \mathrm{~mm}$ thick) did not reach a rejection line of the waterproof coating during the research time.

As shown in line chart (Fig. 7-8) failure in the functioning of $\mathrm{X} 1$ waterproof coating $2 \mathrm{~mm}$ and $3 \mathrm{~mm}$ thick happened on the $14^{\text {th }}$ day.

\section{CONCLUSIONS}

Variating the number of layers of waterproof coating yielded the following results. During 45 days the sufficient effectiveness of X1 waterproof coating is reached on model A when applying 3 layers $4 \mathrm{~mm}$ thick, on model B when applying 3 layers $3 \mathrm{~mm}$ and $4 \mathrm{~mm}$ thick, both in sandy and clay soil conditions.

Increasing the number of layers of the X2 waterproof coating up to two layers $5 \mathrm{~mm}$ and $6 \mathrm{~mm}$ thick provides a barrier to a capillary stream during 45 days. At the same time, as it was noted earlier, the same waterproof coating $0.7 \mathrm{~cm}$ with one layer also protects.

Thus, the research has established that the intensity of capillary absorption is affected by porosity of shell limestone, soil conditions and types of waterproof coatings.

Decrease in intensity of capillary absorption is promoted by applying the horizontal waterproof coating.

The most efficient waterproof coating accepted both for clay and for sandy conditions, is the cement and sand mortar with 5\% hydrophobic additive (from the mass of cement) 7 mm thick.

\section{REFERENCES}

[1] Zarubina L. P. (2011). Gidroizolyatsiya konstruktsiy, zdaniy $i$ sooruzheniy. St. Petersburg: BHV-St. Petersburg, 28 p.

[2] Polyakov, S. V. (1973). Kamennaya kladka iz pil'nykh izvestnyakov. Polyakov S. V., Izmaylov, Yu. V., Konovodchenko, V. I., Orudzhev, F. M., \& Polyakov N. D., Chisinau.

[3] Shcherbina, S. N. (2008). Vliyaniye kapillyarnogo vsasyvaniya vlagi i yego ispareniya na vlagosoderzhaniye sten zdaniy. Shcherbina S. N., Bronik, O. N., Sternik, T. N., \& Danchenko, G. A., Vesnik ODABA No. 32, Odessa.

[4] Dmitriyeva, N. V. (2015). Analiz innovatsionnykh metodov vosstanovleniya gidroizolyatsii konstruktsiy iz izvestnyakarakushechnika. Dmitriyeva, N. V. \& Gostrik, A. O., Vesnik $O D A B A$ No. 62 Odessa, 111-116.

[5] https://ukr.sika.com/ru/solutions_products/02/02a024/02a024s a004.html (Accessed in December 2018)

[6] http://gidrozit.com.ua/sukhiesmesi/product/view/1/21.html (Accessed in December 2018)
Authors' contacts:

Nina Dmitriyeva

Odessa State Academy of Civil Engineering and Architecture, Ukraine, 65029, Odessa, Didrihsona str. 4

dmitrieva.nv76@gmail.com

Oleg Popov

Odessa State Academy of Civil Engineering and Architecture, Ukraine, 65029, Odessa, Didrihsona str. 4

oleg.a.popov@gmail.com

Olga Grin

GOU "Pridnestrovian State University named after TG Shevchenko", Moldova, 3300, Tiraspol, 25 of October str., 128

grin@bpfpgu.ru 